\section{Thermal expansion of oxide systems on the basis of $\mathrm{ZrO}_{2}$}

VLADIMIR V. PROMAKHOV - Tomsk State University, Tomsk (Russia)

SvetLana P. BUYAKOVA - Tomsk State University, Tomsk (Russia)

VANDA ILLAVSZKY - University of Miskolc, Miskolc (Hungary)

Sergey N. KULKOV - Tomsk State University, Tomsk (Russia) - Institute of Strength Physics and Materials Science SB RAS, Tomsk (Russia) • kulkov@ispms.tsc.ru

LÁszLó A. GÖMZE - University of Miskolc, Miskolc (Hungary) - IGREX Engineering Service Ltd, Igrici (Hungary) - igrex2009@yandex.ru

Received: 27. 08. 2014. " Érkezett: 2014. 08. 27. " http://dx.doi.org/10.14382/epitoanyag-jsbcm.2014.15

\begin{abstract}
The structure and phase composition of the ceramic-based system $\mathrm{ZrO}_{2}-\mathrm{MgO}$ is studied. The dependence between the structural-phase state and the coefficient of thermal expansion of ceramic materials based on solid solutions $\mathrm{ZrO}_{2}-\mathrm{MgO}$ is demonstrated. The coefficient of thermal expansion of the system increases proportionally to the increase of the $\mathrm{MgO}$ content. The thermal expansion of the $\mathrm{ZrO}_{2}-\mathrm{MgO}$ ceramic materials can be described in the framework of the mixture rule taking into account the phase composition of $\mathrm{ZrO}_{2}$ and the amount of magnesia grains in the matrtix. Keywords: $\mathrm{ZrO}_{2}-\mathrm{MgO}$ solid solutions, coefficient of thermal expansion, mixture rule
\end{abstract}

\section{Introduction}

Today's industrial progress leads to the need for materials that retain their functional properties when operating under high temperature conditions [1-6]. Good candidates in this respect are the oxide ceramic materials, particularly the ones on the basis of $\mathrm{ZrO}_{2}-\mathrm{MgO}$ solid solutions. Materials of the $\mathrm{ZrO}_{2}-$ $\mathrm{MgO}$ system are known to have high melting temperature, chemical resistance, crack resistance and strength, which make possible their operation under high temperature conditions in aggressive media. Of particular importance in such conditions is the thermal expansion of the material. The literature provides the values of the coefficient of thermal expansion for stabilized $\mathrm{ZrO}_{2}$ [7-10], but neither the qualitative nor the quantitative composition of the materials is considered. It is therefore pertinent to study the thermal expansion of the $\mathrm{ZrO}_{2}-\mathrm{MgO}$ systems of variable composition.

The aim of this paper is to study the structure and phase composition and their relation to the coefficient of thermal expansion of the $\mathrm{ZrO}_{2}-\mathrm{MgO}$ ceramic materials.

\section{Experimental procedure}

$\mathrm{ZrO}_{2}-\mathrm{MgO}$ ceramics of the following compositions have been studied: $\mathrm{ZrO}_{2}+8.6$ mole\% $\mathrm{MgO}$ (hypoeutectoid); $\mathrm{ZrO}_{2}+13.9$ mole\% $\mathrm{MgO}$ (eutectoid); $\mathrm{ZrO}_{2}+25.4$ mole\% $\mathrm{MgO}$, $\mathrm{ZrO}_{2}+35$ mole\% $\mathrm{MgO}, \mathrm{ZrO}_{2}+43.3$ mole\% $\mathrm{MgO}$ (hypereutectoid).

Specimens were compacted from powders produced by thermal decomposition of salt solutions in low-temperature plasma. Powder compaction was carried out under a pressure of $70 \mathrm{MPa}$. The compacts were sintered at $1650^{\circ} \mathrm{C}$ and then subjected to one hour of isothermal exposure in air.

The structure of the obtained ceramics was analyzed by scanning electron microscopy on a microscope Philips SEM 515. The accelerating voltage was $30 \mathrm{kV}$. Specimens for SEM examination were mirror polished with diamond pastes of different sizes.
Vladimir V. Promakhov, PhD has finished the Tomsk State University in 2008. He is got scientific degree "Candidate of Technical Sciences" at Institute of Strength Physics and Materials Science SB RAS in 2012.

Theme of his Ph.D. work was "Structure and phases in $\mathrm{ZrO}_{2}-\mathrm{MgO}$ after thermoloading and its mechanical properties" under guidance Prof. Buyakova. V.V. Promakhov is author or co- author of 10 articles and 1 Russian patent.

Prof. Svetlana P. Buyakova Doctor of Sciences from 2008, full Professor from 2013. She is specialist in material sciencesof ceramic and ceramic matrix composites based on oxides and carbides. She is author and co-author more than 100 papers. Three Ph.D. students and one person makes they dissertations under her guidance in period 2010-2013. Now, she is chief scientist in IS PMS RAS and professor in Tomsk State University and Tomsk Polytechnic University. Her teaching experience: Introduction to Materials Science, Fundamentals of Materials Engineering, Materials and their Applications.

Vanda Illavszky

is a BSc student at the Materials Science and Engineering Faculty in University of Miskolc (Hungary) and under guidance Prof. Gömze she is participating in the research works which are made under collaboration agreement between Tomsk State University (Russia) and University of Miskolc (Hungary).

Prof. Sergey N. Kulkov Prof. Kulkov is head of Department of Ceramics in the Institute of Strength Physics and Materials Science of the Russian Academy of Science since 1989. He has got scientific degrees "Doctor of Physics and Mathematical Sciences" in 1990. Since 1992 he's working as professor both in Tomsk State University and in Tomsk Polytechnic University. In 1997 he had a Soros Professor grant. His research works are represented in 5 books, more than 150 articles, 18 patents and many International Symposiums and Conferences. At present he is head of department „Theory of Strength and Mechanic of Solids", member of "The American Ceramic Society" of "The APMI International" and the DYM AT Society (France).

Prof. László A. Gömze Establisher (in July 1st, 1999) and head of Department of Ceramics and Silicate Engineering in the University of Miskolc, Hungary. Since then 7 students from the department have successfully completed their PhD theses and 4 of them were managed by Prof. Gömze. He is author or coauthor of 2 patents, 5 books and more than 250 scientific papers. Recently, he is the chair of the International Organization Board of ic-cmtp3 the $3^{\text {rd }}$ International Conference on Competitive Materials and Technological Processes (2014) and ic-rmm2the $2^{\text {nd }}$ International Conference on Rheology and Modeling of Materials (2015).

The phase composition and crystal structure parameters were studied by X-ray diffraction patterns obtained using filtered $\mathrm{CuK}_{\alpha}$ radiation. The zirconia phase content was estimated by the ratio of the integral intensities of the tetragonal and cubic diffraction lines I(111), and the monoclinic diffraction lines I(111), I(-111).

Thermal expansion was measured using a mechanical dilatometer in air. The specimen temperature was increased at a rate of $10^{\circ} \mathrm{C} / \mathrm{min}$. The specimens were heated up to $1100^{\circ} \mathrm{C}$, which, according to the phase diagram of the $\mathrm{ZrO}_{2}-\mathrm{MgO}$ system, corresponds to the temperature of transition from the low-temperature monoclinic $\mathrm{ZrO}_{2}$ phase to the hightemperature tetragonal modification of $\mathrm{ZrO}_{2}$.

\section{Results and discussion}

The SEM images of the $\mathrm{ZrO}_{2}-\mathrm{MgO}$ ceramics structure with different magnesia content are given in Fig. 1. The structure 


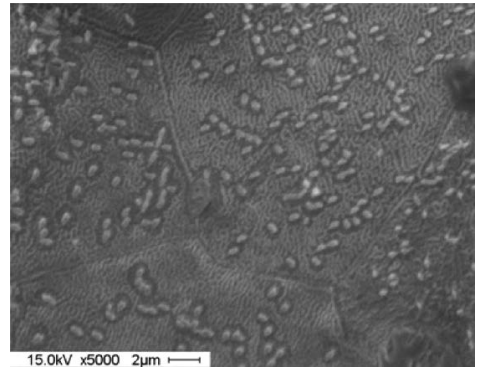

a)

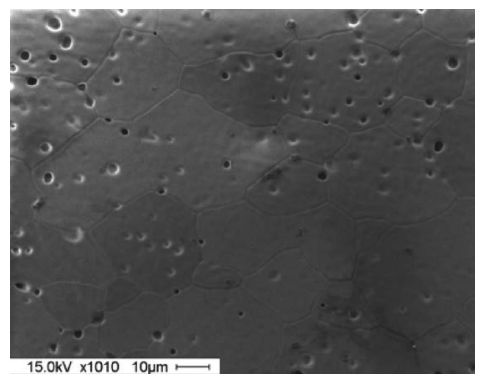

b)

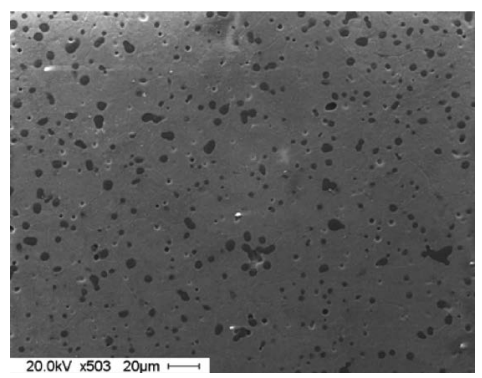

c)

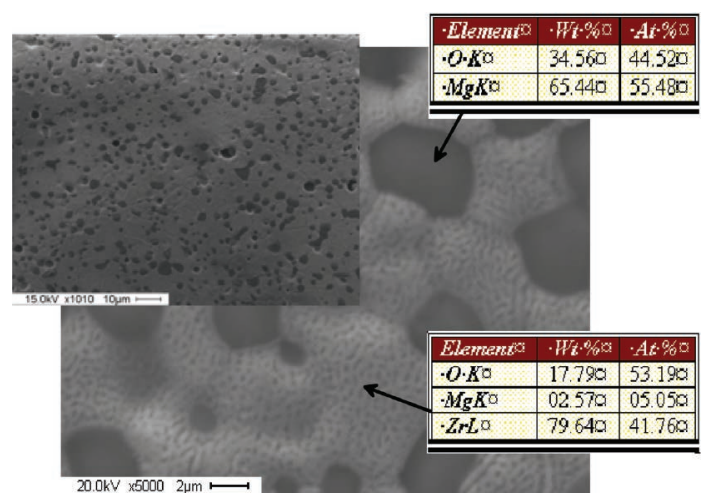

d)

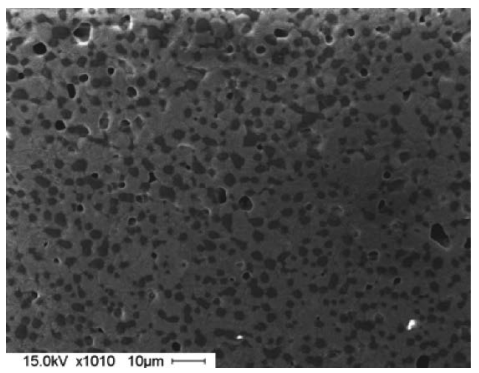

e)

$a-\mathrm{ZrO}_{2}(8.6$ mole $\% \mathrm{MgO}), b-\mathrm{ZrO}_{2}(13.9$ mole $\% \mathrm{MgO}) ; c-\mathrm{ZrO}_{2}(25.4 \mathrm{~mole} \% \mathrm{MgO})$, $d-\mathrm{ZrO}_{2}$ (35 mole $\left.\% \mathrm{MgO}\right) ; e-\mathrm{ZrO}_{2}$ (43.3 mole $\% \mathrm{MgO}$ )

Fig. 1. SEM images of the ceramics structure:

1. ábra A vizsgált cirkon-kerámiák anyagszerkezetének SEM felvételei of the specimens of the hypoeutectoid composition shows lenticular grains of the tetragonal $\mathrm{ZrO}_{2}$ phase, along with grains of the cubic $\mathrm{ZrO}_{2}$ solid solution (Fig. 1a). The structure of the $\mathrm{ZrO}_{2}(13.9$ mole\% $\mathrm{MgO}$ ) ceramics is represented in Fig. 1b. This composition is characterized by grains of the cubic modification of $\mathrm{ZrO}_{2}[11,12]$. The specimens of the hypereutectoid compositions have magnesia inclusions in the $\mathrm{ZrO}_{2}$ matrix. In this case, the content of $\mathrm{MgO}$ inclusions increased from 9 to $22 \%$ with the magnesia content growth in the $\mathrm{ZrO}_{2}-\mathrm{MgO}$ system from 25.4 to $43.3 \mathrm{~mole} \%$, respectively.

According to $\mathrm{X}$-ray phase analysis data, the $\mathrm{X}$-ray diffraction patterns of the hypoeutectoid ceramics have reflections from three zirconia phases, namely, cubic $\left(\mathrm{C}-\mathrm{ZrO}_{2}\right)$, tetragonal $\left(\mathrm{T}-\mathrm{ZrO}_{2}\right)$ and monoclinic $\left(M-\mathrm{ZrO}_{2}\right)($ Fig. 2), with the monoclinic phase content increasing with the growing magnesia content in the initial mixture.

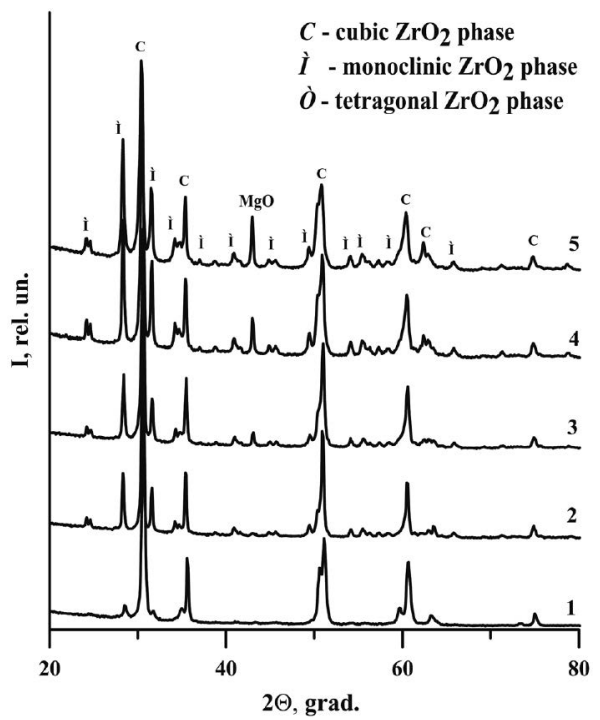

$1-\mathrm{ZrO}_{2}$ (8.6 mole\% $\mathrm{MgO}$ ); $2-\mathrm{ZrO}_{2}\left(13.9\right.$ mole\% $\mathrm{MgO}$ ); $3-\mathrm{ZrO}_{2}(25.4$ mole $\% \mathrm{MgO}$ ); $4-\mathrm{ZrO}_{2}$ (35 mole\% $\left.\mathrm{MgO}\right) ; 5-\mathrm{ZrO}_{2}(43.3$ mole $\% \mathrm{MgO})$.

Fig. 2. X-ray diffractograms of the ceramics of the $\mathrm{ZrO}_{2}-\mathrm{MgO}$ system:

2. ábra $\mathrm{A} \mathrm{ZrO}_{2}-\mathrm{MgO}$ kerámiák röntgen-diffraktogramjai

The phase composition of the eutectoid ceramics is represented by the high-temperature cubic modification of $\mathrm{ZrO}_{2}$. The X-ray diffraction patterns of the hypereutectoid ceramics have, along with the $\mathrm{ZrO}_{2}$ reflections, diffraction maxima corresponding to $\mathrm{MgO}$.

Measurements of the coefficient of thermal expansion of the studied materials (Fig. 3) showed that the coefficient of thermal expansion measured in the temperature range 400-1250 K depends linearly on the magnesia content in the initial mixture. The measured thermal expansion coefficients agree well with the values calculated by the mixture rule taking into account the phase composition of the studied materials: the content of the monoclinic $\mathrm{ZrO}_{2}$ modification for the composition with 8.6 mole $\% \mathrm{MgO}$ is $15 \%$, which determines low values of the coefficient of thermal expansion equal to $6.7 \cdot 10^{-6} \mathrm{~K}^{-1}$, since, according to the literature data, the coefficient of thermal expansion of the monoclinic $\mathrm{ZrO}_{2}$ phase is $6 \cdot 10^{-6} \mathrm{~K}^{-1}$ and that of the cubic $\mathrm{ZrO}_{2}$ phase is $8 \cdot 10^{-6} \mathrm{~K}^{-1}$. The coefficient of thermal expansion of the eutectoid specimens is defined by thermal 
expansion of the cubic $\mathrm{ZrO}_{2}$ phase, while the main factor that contributes to the thermal expansion of the hypereutectoid specimens is an increase in the amount of magnesia grains in the zirconia matrix.

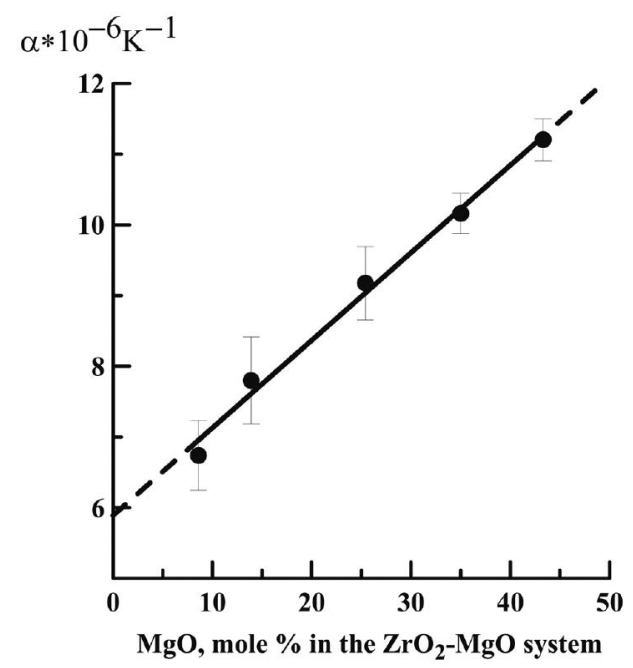

\footnotetext{
Fig. 3. Coefficient of thermal expansion vs. magnesia content in the $\mathrm{ZrO}_{2}-\mathrm{MgO}$ system

3. ábra $\mathrm{A} \mathrm{ZrO}_{2}-\mathrm{MgO}$ kerámiák hötágulási együtthatója a MgO tartalom függvényében
}

In extrapolating the obtained dependence to the zero $\mathrm{MgO}$ content, the coefficient of thermal expansion corresponds to the thermal expansion of the monoclinic $\mathrm{ZrO}_{2}$ modification. In extrapolating the obtained dependence to the $100 \%$ magnesia content, the coefficient of thermal expansion is $14.9 \cdot 10^{-6} \mathrm{~K}$, which is close to the thermal expansion of magnesia equal to $14.4 \cdot 10^{-6} \mathrm{~K}$. So, the coefficient of thermal expansion of the $\mathrm{ZrO}_{2}-\mathrm{MgO}$ system is defined by the mixture rule taking into account the phase composition and amount of magnesia inclusions in the $\mathrm{ZrO}_{2}$ matrix.

\section{Conclusions}

It is found that the coefficient of thermal expansion is governed by the phase composition of the sintered ceramics, with a ratio of the fractions of the high- and low-temperature $\mathrm{ZrO}_{2}$ modifications and the amount of magnesia grains in the $\mathrm{ZrO}_{2}$ matrix. The coefficient of thermal expansion of the system increases proportionally to the increase of the $\mathrm{MgO}$ content. The thermal expansion of the $\mathrm{ZrO}_{2}-\mathrm{MgO}$ ceramic materials can be described in the framework of the mixture rule taking into account the phase composition of $\mathrm{ZrO}_{2}$ and the amount of magnesia grains in the matrtix.

\section{Acknowledgments}

Part of this work has been financially supported by Tomsk State University Competitiveness Improvement Program and RF President Grant MK-5883.2014.8.

\section{References}

[1] N. I. Ershova and I. Yu. Kelina: High-temperature wear-resistant materials based on silicon nitride, (2009) Építőanyag, vol. 61, pp. 34-37, http://dx.doi.org/10.14382/epitoanyag-jsbcm.2009.6
[2] L. A. Gömze and L. N. Gömze: Hetero-modulus nanoparticles reinforced corundum matrix CMC with extreme wear and thermal shock resistances, Mat. Sci. Forum, 2010, vol. 659, pp. 165-170, http://dx.doi.org/10.4028/www.scientific.net/MSF.659.165

[3] V. Lutsyk and A. Zelenaya: Crystalisation paths in $\mathrm{SiO}_{2}-\mathrm{Al}_{2} \mathrm{O}_{3}-\mathrm{CaO}$ system as genotype of silicate materials, (2013) Építőanyag, vol. 65, pp. 34-38, http://dx.doi.org/10.14382/epitoanyag-jsbcm.2013.7

[4] Xiao Lei Lia at all: Study on Heat Treatment of Aluminum Nitride $\left(\mathrm{Y}_{2} \mathrm{O}_{3}\right)$ Ceramics Sintered at High Pressure, (2011) Advanced Materials Research, vol. 266 , pp. $68-71$,

http://dx.doi.org/10.4028/www.scientific.net/AMR.266.68

[5] J. Mara: Advanced ceramic materials for next-generation nuclear applications, (2011) IOP Conf. Ser. MSE, vol. 18, http://dx.doi.org/10.1088/1757-899X/18/16/162001

[6] J. Sumita, I. Fujita, T. Shibata, T. Makita, T. Takagi, E. Kunimoto, K. Sawa, W. Kim and J. Park: Study on Fracture Behavior of 2D-C/C Composite for Application to Control Rod of Very High Temperature Reactor, (2011) IOP Conf. Ser. MSE, vol. 18, http://dx.doi.org/10.1088/1757-899X/18/16/162010

[7] A.G., Evans, Perspectives on the development of high-toughness ceramics, J. Am. Ceram. Soc., 1990, vol. 73, no. 2, pp. 187-206

[8] M. Biswas, C. S. Kumbhar, and D. S. Gowtam: Characterization of Nanocrystalline Yttria-Stabilized Zirconia: An In Situ HTXRD Study, (2011) ISRN Nanotechnology, http://dx.doi.org/10.5402/2011/305687

[9] H. Schubert: Anisotropic Thermal Expansion Coefficients of $\mathrm{Y}_{2} \mathrm{O}_{3}$ Stabilized Tetragonal Zirconia, (1986) Journal of the American Ceramic Society, vol. 69, pp. 270-271

[10] J.R. Kelly and I. Denry: Stabilized zirconia as a structural ceramic: An overview, (2008) Dental Materials, vol. 24, pp. 289-298, http://dx.doi.org/10.1016/j.dental.2007.05.005

[11] Buyakova, S.P., Promakhov, V.V., and Kulkov, S.N., Thermal tests and their effect on micro- and macrostructure of nanocrystalline $\mathrm{ZrO}_{2}$, Powder Metall. Met. Ceram., 2012, vol. 51, no. 5-6, pp. 267-272.

[12] G. Sedmale, I. Sperberga, A. Hmelov and I. Steins: Characterisation of mullite $-\mathrm{ZrO}_{2}$ ceramics prepared by various methods, (2011) IOP Conf. Ser. MSE, vol. 18 ,

http://dx.doi.org/10.1088/1757-899X/18/22/222014

$\underline{\text { Ref.: }}$

Promakhov, Vladimir V. - Buyakova, Svetlana P. - Illavszky, Vanda - Kulkov, Sergey N. - Gömze, László A.: Thermal expansion of oxide systems on the basis of $\mathrm{ZrO}$

Építőanyag - Journal of Silicate Based and Composite Materials, Vol. 66, No. 3 (2014), 81-83. p.

http://dx.doi.org/10.14382/epitoanyag-jsbcm.2014.15

\section{$\mathrm{ZrO}_{2}$ alapú kerámia rendszerek hőtágulása}

Jelen munkában a szerző́k a $\mathrm{ZrO}_{2}$-MgO alapú kerámia rendszerek anyagszerkezete, fázis összetétele és a hōtágulási együttható kapcsolatát vizsgálják. Az elvégzett vizsgálatok azt igazolják, hogy az eltérố kémiai összetételú $\mathrm{ZrO}_{2}-\mathrm{MgO}$ szilárd oldatok hôtágulási együtthatója jelentôs mértékben függ az anyagszerkezeti szerkezeti fázisoktól. Ugyanakkor az adott vizsgálati hômérsékleten a MgO tartalom növelésével arányosan növekszik a hôtágulási együttható. A kutatás eredményeként a $\mathrm{ZrO}_{2}-\mathrm{MgO}$ kerámia rendszerhez tartozó anyagok hôtágulási együtthatója a keverék szabály figyelembevételével leírható az adott $\mathrm{ZrO}_{2}$ fázis jelenléte és a MgO szemcsék anyag-matrtixon belüli mennyiségének függvényében. Kulcsszavak: $\mathrm{ZrO}_{2}-\mathrm{MgO}$ szilárd oldatok, hôtágulási együttható, keverék szabály 